\title{
An unusual cause of upper gastrointestinal system bleeding: Duodenal varices
}

\author{
Üst gastrointestinal sistem kanamasının nadir bir nedeni: Duodenal varisler \\ Ömer Yılmaz, Hilmi Ataseven*
}

Department of Gastroenterology (Assoc. Prof. Ö. Yılmaz, MD), Atatürk University School of Medicine, TR-25240 Erzurum, Department of Gastroenterology (Assoc. Prof. H. Ataseven, MD), Cumhuriyet University School of Medicine, TR-58140 Sivas

\begin{abstract}
Duodenal varices are an uncommon site of hemorrhage in patients with portal hypertension, but their rupture is a serious and often fatal event. We report the case of a 27-year- old man with liver cirrhosis who presented with upper gastrointestinal bleeding. Upper gastrointestinal endoscopy revealed nodular varices in the second portion of the duodenum which were considered to be the source of bleeding. We decided to inject N-butyl-2-cyanoacrylate (Histoacryl), an adhesive agent, and achieved successful hemostasis. We conclude that endoscopic injection sclerotherapy (EIS) with Histoacryl is an effective treatment option for ruptured duodenal varices.
\end{abstract}

Keywords: Duodenal varices, upper gastrointestinal hemorrhage, hemostasis

\section{Özet}

Duodenal varisler, portal hipertansiyonu olan hastalarda nadir fakat ciddi ve ölümcül bir kanama nedenidir. Üst gastrointestinal kanama ile gelen karaciğer sirozu olan 27 yaşında bir erkek hastayı sunduk. Üst gastrointestinal sistem endoskopisinde, kanama kaynağının duodenum ikinci kısımdaki nodüler varisden olduğunu gördük. Biz adheziv bir ajan olan N-butyl-2-cyanoacrylate (Histoacryl) enjekte ettik ve başarılı bir hemostaz sağladık. Histoacryl ile endoskopik enjeksiyon skleroterapisinin kanayan duodenal varisler için etkili bir tedavi seçeneği olduğuna inanıyoruz.

Anahtar sözcükler: Duodenal varisler, üst gastrointestinal kanama, hemostaz

Geliş tarihi/Received: October 01, 2011; Kabul tarihi/Accepted: May 03, 2012

\section{*Corresponding author:}

Dr. Hilmi Ataseven, Gastroentroloji Anabilim Dalı, Cumhuriyet Üniversitesi Tıp Fakültesi, TR58140 Sivas. E-posta: hilmiataseven@yahoo.com

\section{Introduction}

Bleeding of duodenal varices is a rare complication of cirrhosis and this situation is lifethreatening. These bleeding are seen in $0.4 \%$ of patients with portal hypertension [1]. In patients with portal hypertension and upper gastrointestinal bleeding, it is essential to investigate the source of hemorrhage, keeping in mind the possibility of variceal bleeding from the duodenum. The duodenal bulb is the most common site of duodenal varices, but endoscopy should not be limited to the bulbar region, as varices in the third and fourth portions have also been reported [2]. The diagnosis and management of this disease is difficult. At this time, no consistent hemostatic procedure has been established, in spite of the fatal nature of this disease [3]. We report a patient with duodenal varices taken under control after endoscopic injection sclerotherapy (EIS) with N- butyl-2-cyanoacrylate. 


\section{Case report}

We report the case of a 27-year-old man diagnosed five years ago as cirrhosis due to hepatitis B and diabetes mellitus who presented with hematemesis and melena. His hemoglobin level had decreased from $12.8 \mathrm{~g} / \mathrm{dL}$ to $8.1 \mathrm{~g} / \mathrm{dL}$ within two days. At admission, he was in state of deep hepatic coma. His blood pressure was $80 / 50 \mathrm{mmHg}$ and pulse rate 99 beats/min at admission. His palpebral conjunctivae were pale, and spider angiomas were observed on his chest. The liver was not palpable, but a moderate degree of ascites was present. Severe edema was present in the lower extremities. Laboratory studies (normal values in parentheses) revealed the following: white blood cell: $4.7 \times 10^{3} / \mu \mathrm{L}\left(4.3-10.310^{3} / \mu \mathrm{L}\right)$, hemoglobin: $8.1 \mathrm{~g} / \mathrm{dL}(13.6-17.2 \mathrm{~g} / \mathrm{dL})$, hematocrit: $24 \%$ (39.5-50.3), and thrombocyte count: $59.7 \times 10^{3} / \mu \mathrm{L}(156-373103 / \mu \mathrm{L})$. Total serum protein level was $4.7 \mathrm{~g} / \mathrm{dL}(6.0-8.0 \mathrm{~g} / \mathrm{dL})$ and serum albumin $2.1 \mathrm{~g} / \mathrm{dL}(3.5-5.2 \mathrm{~g} / \mathrm{dL})$. Other pertinent laboratory data included aspartate aminotransferase: $41 \mathrm{IU} / \mathrm{L}$ (0-37 IU/L), alanine aminotransferase:73 IU/L (0-41 IU/L), blood urea nitrogen: $41 \mathrm{mg} / \mathrm{dL}(8-23$ $\mathrm{mg} / \mathrm{dL})$, creatinine: $1.1 \mathrm{mg} / \mathrm{dL}(0.9-1.3 \mathrm{mg} / \mathrm{dL})$, prothrombin time $: 21 \mathrm{~s}(10-13 \mathrm{~s})$, ammonia: $211 \mu \mathrm{g} / \mathrm{dL}(30-86 \mu \mathrm{g} / \mathrm{dL})$, and total serum bilirubin: $1.9 \mathrm{mg} / \mathrm{dL}(0.2-1.2$ $\mathrm{mg} / \mathrm{dL}$ ). Hepatitis B surface antigen was positive. Liver function was evaluated as grade $\mathrm{C}$ according to the Child-Pugh classification. Abdominal ultrasonography showed atrophic and blunt-margined lobes of the liver, pooling of ascites under the diaphragm, and marked splenomegaly. Duplex ultrasound scan did not reveal splenic or portal vein thrombosis. Lactulose treatment was started, he could gain his consciousness. The patient was managed with intravenous proton pump inhibitor, an octreotide infusion at $50 \mu \mathrm{g} / \mathrm{hr}$ and fresh-frozen plasma to correct a prothrombin time of 21 seconds. When an emergency endoscopic examination was performed, large nodular varices with spurting bleeding were observed in the second portion of the duodenum (Figure 1).

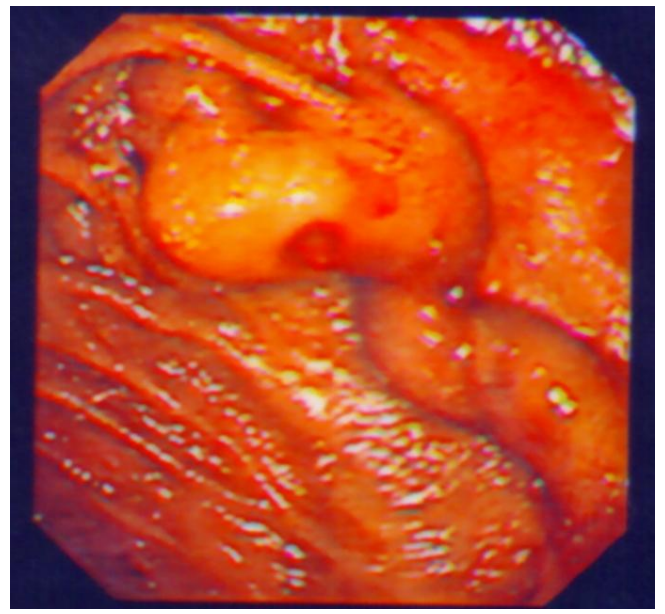

Figure 1. Endoscopic view of a bleeding duodenal varix, approximately $1.5 \mathrm{~cm}$ in diameter, at the inferior duodenal angle.

After washing out the blood, the proximal aspect of the major duodenal papilla close to duodenal varices could not be identified. Grade 2 esophageal varices without any hemorrhage point were observed; there were no gastric varices. Active bleeding from the duodenal varices was confirmed. We decided to inject $1.5 \mathrm{~mL}$ of an N-butyl-2cyanoacrylate (Histoacryl; Braun-Melsungen, Germany) (1 mL) / Lipiodol (LaboratoireGuerbet, France) $(0.5 \mathrm{~mL})$ mixture under endoscopic control, and performed intravariceal sclerotherapy using a flexible endoscope with a 23 -gauge transparent Teflon injector (Wilson-Cook, Winston Salem, NC, USA) and achieved successful hemostasis.

Hemorrhage was controlled in our patient with medical measures and sclerotherapy. Three days after EIS, the duodenal varices demonstrated no change in size and revealed post-EIS ulcer without any sign of recurrent bleeding (Figure 2). His blood pressure was stabilized, and there was no evidence of melena or hematemesis. 


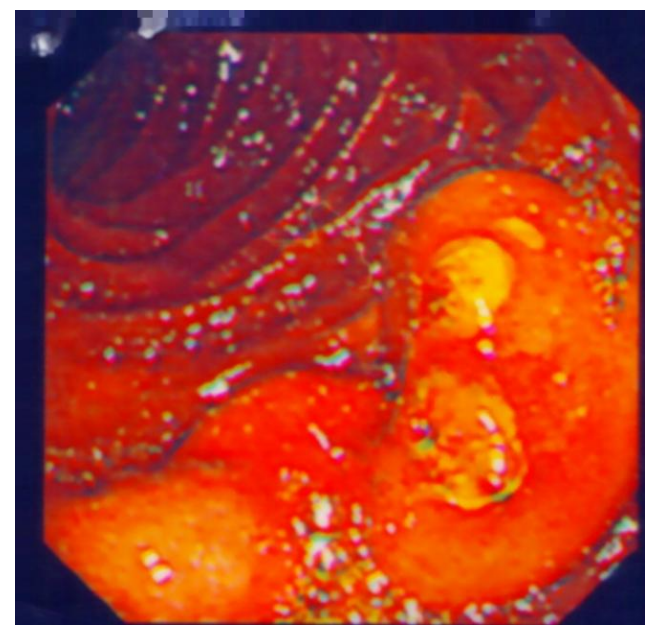

Figure 2. Endoscopic view of clean-based ulcers resulting from the endoscopic sclerotherapy.

\section{Discussion}

Portal hypertension is a common complication of liver cirrhosis. Varices may take place along the entire gastrointestinal tract [4]. While variceal hemorrhage is one of the major causes of death in patients with portal hypertension, duodenal varices are seldom considered in the spectrum of its complications [5]. Blood flow in duodenal varices is so rapid that bleeding often becomes profuse. For this reason, the prognosis is poor in a patient who has bleeding from duodenal varices and mortality is high (40\%). To date, a definitive treatment for bleeding duodenal varices has not been recognized [1]. Treatment options for duodenal varices have diversified in recent years, and include surgery (e.g., variceal ligation, duodenal resection, and extrahepatic portosystemic shunts), interventional radiologic procedures (IVR) [e.g., percutaneous transhepatic obliteration (PTO), transileocolic vein obliteration (TIO), transjugular intrahepatic portosystemic shunt (TIPS), and balloon-occluded retrograde transvenous obliteration (B-RTO)], and endoscopic procedures [e.g., endoscopic variceal ligation (EVL) and endoscopic injection sclerotherapy (EIS)]. However, none of these treatment options has been investigated in large series of patients. There is no clear consensus about the best method for treating duodenal varices. Thus, treatment of duodenal varices must be planned on a case-by-case basis $[3,6]$. Surgical treatment becomes an aggressive approach in these patients [4]. In many reported cases, a $30 \%$ mortality rate was found in patients with severely decompensated cirrhosis and poor physical status, with this rate reaching $100 \%$ in Child class $\mathrm{C}$ patients [3, 6-8]. As none of the IVR techniques has been investigated in large series of patients with duodenal varices, it is not clear which modality is the most successful. PTO, TIO and TIPS are effective for a transient hemostasis of ruptured duodenal varices, but long-term outcome remains vague. Endoscopic procedures are less invasive with respect to IVR, and seem more promising for emergency bleeding duodenal varices since they are easier and faster to perform [8]. Endoscopic variceal ligation seems to be an effective treatment method for patients with bleeding duodenal varices. EVL has no systemic complications. Although EVL appears to be appropriate for achieving hemostasis in emergency situations, it has a restriction in that duodenal varices larger than $15 \mathrm{~mm}$ cannot be ligated. Identifying the papilla is important to avoid its inclusion within banded tissue, as biliary obstruction can result from its banding [1]. Duodenal varices were successfully treated with endoscopic injection of various agents such as $\mathrm{N}$ butyl-2-cyanoacrylate (Histoacryl), ethanolamine, sodium morrhuate, and thrombin [7]. Histoacryl is injected inside the varices, polymerizes at once and causes embolization. Because Histoacryl bring about an inflammatory reaction and stimulates fibrotic changes in the ulcer [2]. EIS with Histoacryl is accepted to be useful for treating duodenal varices. 
However, there are also potential risks of tissue damage, perforation and progression of the bleeding [1]. Imperio et al. [9] reported that injection of Histoacryl achieved hemostasis in about $90 \%$ of 48 patients with actively bleeding upper gastrointestinal tract varices, including duodenal varices. Both ligation and sclerotherapy are similarly effective in achieving variceal eradication in patients with cirrhosis [10]. In this case, we used EIS with Histoacryl as a means of controlling bleeding from duodenal varices.

In conclusion, EIS with Histoacryl is less invasive compared with IVR and surgical treatment. This technique may be useful for obtaining hemostasis among patients with ruptured duodenal varices accompanied by severe liver dysfunction and a poor general condition.

\section{References}

1. Akazawa Y, Murata I, Yamao T, Yamakawa M, Kawano Y, Nomura N, Isomoto H, Mizuta Y, Murase K, Kohno S. Successful management of bleeding duodenal varices by endoscopic variceal ligation and balloon-occluded retrograde transvenous obliteration. Gastrointest Endosc 2003; 58: 794-7.

2. Ota K, Shirai Z, Masuzaki T, Tanaka K, Higashihara H, Okazaki M, Arakawa M. Endoscopic injection sclerotherapy with n-butyl-2-cyanoacrylate for ruptured duodenal varices. J Gastroenterol 1998; 33: 550-5.

3. Ota K, Okazaki M, Higashihara H, Kokawa H, Shirai Z, Anan A, Kitamura Y, Shijo H. Combination of transileocolic vein obliteration and balloon-occluded retrograde transvenous obliteration is effective for ruptured duodenal varices. J Gastroenterol 1999; 34: 694-9.

4. Tsurusaki M, Sugimoto K, Matsumoto S, Izaki K, Fukuda T, Akasaka Y, Fujii M, Hirota S, Sugimura K. Bleeding Duodenal Varices Successfully Treated with Balloon-Occluded Retrograde Transvenous Obliteration (B-RTO) Assisted by CT During Arterial Portography. Cardiovasc Intervent Radiol 2006; 29: 1148-51.

5. McAlister VC, Al-Saleh NA. Duodenal dearterialization and stapling for severe hemorrhage from duodenal varices with portal vein thrombosis. Am J Surg 2005; 189: 49-52.

6. Sonomura T, Horihata K, Yamahara K, Dozaiku T, Toyonaga T, Hiroka T, Sato M. Ruptured duodenal varices successfully treated with balloon-occluded retrograde transvenous obliteration: usefulness of microcatheters. AJR Am J Roentgenol 2003; 181: 725-7.

7. Bosch A, Marsano L, Varilek GW. Successful obliteration of duodenal varices after endoscopic ligation. Dig Dis Sci 2003; 48: 1809-12.

8. Machida T, Sato K, Kojima A, Takezawa J, Sohara N, Kakizaki S, Takagi H, Mori M. Ruptured duodenal varices after endoscopic ligation of esophageal varices: an autopsy case. Gastrointest Endosc 2006; 63: 352-4.

9. D'Imperio N, Piemontese A, Baroncini D, Billi P, Borioni D, Dal Monte PP, Borrello P. Evaluation of undiluted N-butyl-2-cyanoacrylate in the endoscopic treatment of upper gastrointestinal tract varices. Endoscopy 1996; 28: 239-43.

10. Zargar SA, Javid G, Khan BA, Yattoo GN, Shah AH, Gulzar GM, Singh J, Rehman BU, Din Z. Endoscopic ligation compared with sclerotherapy for bleeding esophageal varices in children with extrahepatic portal venous obstruction. Hepatology 2002; 36: 666-72. 